\title{
Introdução a elementos da obra de Henri Lefebvre e a Geografia
}

\section{Amélia Luisa Damiani $^{1}$}

RESUMO: Uma busca de teoria e método configura o trajeto para situar a produção do espaço, fortemente influenciado por Henri Lefebvre, como pensador marxista do século XX, cujo projeto inclui esta categoria e encontra seu lugar numa teoria social crítica. A relação com o conhecimento geográfico é nossa preocupação central. Fomos definindo um movimento do pensamento geográfico, circunstanciado por esta influência, demarcando uma significativa atualização conceitual da Geografia.

Palavras-chave: Geografia; Henri Lefebvre; lógica dialética; produção do espaço.

ABSTRACT: The search for a theory and a method is the focus to give meaning to the production of space, heavily influenced by Henri Lefebvre as a twentieth century Marxist thinker whose project includes this category and find its place within a critical social theory. The relation with the knowledge of Geography is our central preoccupation. We tried to describe the movement of geographical thought in the context of this influence, providing the background for a decisive conceptual development in Geography.

Key-words: Geography; Henri Lefebvre; dialectical logic; production of space.

\section{INTRODUÇÃO}

\section{O Trajeto}

A Geografia produzida na Universidade de São Paulo, através do Departamento de Geografia, ao longo de sua história, a rigor, jamais pôde ser confundida com o exercício de perspectivas estritamente empiristas. Esta interpretação sabota uma história real da disciplina no Brasil, através de São Paulo, desviando o sentido do processo de conhecimento com a proposição de outros inauguradores de uma nova Geografia.

Não se trata de enaltecer exatamente a escola francesa, presente em sua formação, mas localizar a Geografia da Universidade de São Paulo como aquela que fez parte do projeto de Geografia Crítica no Brasil, a partir de seus fundamentos iniciais; aquela, também, que se antepôs às versões comezinhas de ciência, que a ditadura militar no Brasil, fruto do golpe militar de 1964, compunha como projeto "acadêmico", a exemplo de cursos de estudos sociais, subvertendo e amesquinhando as ciências história e geografia. Esse projeto vingou

\footnotetext{
${ }^{1}$ Graduação em Geografia pela Universidade de São Paulo, mestrado em Geografia (Geografia Humana) pela Universidade de São Paulo, doutorado em Geografia (Geografia Humana) pela Universidade de São Paulo. Professora da Universidade de São Paulo. E-mail: ameluisa@usp.br
} 
fora da Universidade de São Paulo, em inúmeras faculdades particulares que começaram a pipocar. E explica, também e não somente, a formação reduzida em Geografia, do ensino médio e fundamental, pois é das faculdades particulares que, por um período significativo, veio a maioria de seus professores, que, infelizmente, passaram pela alienação científica que esse projeto mercantil, apresentado, ilusoriamente, como acadêmico, constituiu.

Nos anos 1970, nossos professores formaram a geração que resistiu, dentro da USP, à redução do teor científico e filosófico da Geografia. Neste mesmo sentido, negaram a Geografia Quantitativa, que, por outro caminho, era alimento do projeto ditatorial, oferecendo certa base conceitual para a tecnocracia em desenvolvimento. Nós estudávamos a Geografia Teorética e Quantitativa para compreender seus limites; postura que não se baseou, estritamente, numa contraposição ideológica, mas numa visão de mundo, realidade e conhecimento, que a negavam teórica e praticamente.

O debate teórico disciplinar era vivo à nossa época. O professor Pasquale Petrone teve enorme sentido na luta a favor de uma geografia crítica, solidamente teorizada, seriamente analítica. O teor dos seus estudos, que seus escritos revelam, o dizem perfeitamente. $\mathrm{A}$ Geografia Agrária, ensinada por ele, e, depois, a disciplina de pós-graduação, Colonização no Sul do Brasil, reúnem o exercício de uma geografia comprometida com o desvendamento da formação brasileira. Com ele, aprendemos o poder dos latifundiários em nosso país; o significado histórico e geográfico da propriedade privada da terra; a constituição do Brasil como país, contraposta à ideologia de nação, que era corrente como ideário da ditadura militar, que "vivíamos". Ele tinha uma retórica tão expressiva que era possível ver o que apresentava em aula, como sedimentos analíticos do objeto geográfico.

Ele representa aqui outros professores e pesquisadores geógrafos de sua época que, reunidos na USP, tiveram a força intelectual e política de resistir à banalização científica, proposta com violência.

Assim foram, entre os professores, para citar apenas alguns deles, Léa Goldenstein, Manoel Fernando Gonçalves Seabra, Moacyr Marques e, pelo esforço em estudar geografia e fazer parte do projeto de resistência em curso, o professor Armando Corrêa da Silva, formado em Ciências Sociais.

No início dos anos 1970, o professor Nelson de la Corte ministrava a disciplina Geografia Regional dos Estados Unidos. No seu curso, pudemos conhecer o significado da concepção de organização do espaço; à época, um marco conceitual, que, vista da perspectiva histórico- 
genética das concepções geográficas, significou uma mediação científica importante para o que viemos a produzir, depois, enquanto produção do espaço ou produção social do espaço. Experimentamos um tratamento do tema que não se reduzia a uma visão empirista. 0 nordeste norte-americano e seu desenvolvimento industrial, também, reverberavam em nosso país, pela centralidade mundial do processo econômico norte-americano. A partir da concepção de organização do espaço, a noção de região, constituindo-se em unidade econômica e social - totalizante de novos processos sociais - veio a se redefinir. A organização do espaço, por sua vez, aparecia como um nexo complexo dos fenômenos geográficos, cujo fundamento iluminava seu caráter estratégico.

À base desse recurso teórico, a geografia de Pierre George e a de outros contemporâneos da época chegam ao Brasil, como influência recente da escola francesa de Geografia. Esta literatura aparece para nós como o conhecimento basilar, através do qual se constitui nossa formação.

A discussão do significado da regionalização foi amadurecendo a partir de nossos professores, de modo que esta concepção acabou por constituir uma porta de entrada para a interpretação da especificidade da formação brasileira. ${ }^{2}$

O professor Moacyr Marques introduziu na graduação uma preocupação com a metodologia das ciências. Ajudou-nos a pensar mais abstratamente o objeto da Geografia. Rodávamos com ele, no mimeógrafo, o material em textos a ser usado na sala de aula, às vezes, aos finais de semana. Abrir um fosso interpretativo deste período, os anos 1970 e 1980, e localizar os que vieram depois a fazer parte do projeto de nosso Departamento, identificando-os como inauguradores de uma geografia crítica, desmerece aos que vieram antes e aos próprios autores nomeados como tais, pois destrói a história da produção geográfica. A relação entre organização do espaço e produção do espaço, e, também, valorização do espaço, fica atenuada. Nós fomos formados por uma geração que trouxe A Geografia Ativa para a sala de aula; através dela, contestou especializações estritas, que reduziam a Geografia e a tomavam de assalto tecnocraticamente. Todos ganham em magnitude exatamente ao negarmos essa redução espetacularizada.

Estes professores apresentavam os clássicos da Geografia e os termos de sua atualização necessária. Tivemos uma educação geográfica de fôlego tal que, à época,

\footnotetext{
${ }^{2}$ Entre os estudos, a resgatar GOLDENSTEIN, Léa e SEABRA, Manoel Fernando Gonçalves. Divisão territorial do trabalho e nova regionalização. IN: Revista do Departamento. São Paulo: Departamento de Geografia, FFLCH, USP, 1982.
} 
em grupo, traduzíamos os livros em francês, em espanhol, em inglês, que nossos professores nos indicavam e esses livros compunham o acervo a ser lido para as disciplinas. Nesta época, é importante considerar a tradução do professor Armando Corrêa da Silva de A Justiça Social e a Cidade. O professor Armando traduziu e veiculou, inclusive, em primeira mão, antes da publicação, esta obra de David Harvey ${ }^{3}$.

A primeira impressão do livro de Yves Lacoste $A$ geografia serve antes de mais para fazer a guerra aparece na AGB-São Paulo, em 1979. A professora Liliana Laganá traduziu Massimo Quaini e Tonino Bertanini, no mesmo período. ${ }^{4}$

A dinâmica dos estudos geográficos é complexa no período, pois se situa no interior do período da ditadura militar no Brasil, incluindo confrontos políticos sérios,

que vivíamos, inclusive, pela centralidade que o prédio da Geografia e História tem na Cidade Universitária da USP, de São Paulo, e pela visão de mundo que muitos de nossos professores partilhavam conosco. O movimento estudantil reunia membros de diferentes facções em assembleias na pátio do prédio. ${ }^{5}$ Em 1973, choramos a queda e morte de Salvador Allende, no Chile. Houve debates sobre o significado de sua perda, na luta por liberdade e socialismo na América Latina. E nos preocupamos com os exilados brasileiros que lá estavam e sofreriam dura repressão. Brindamos a Revolução dos Cravos, em 1974, com debates e festa. Dentro e fora da sala de aula, questionávamos o "Milagre Brasileiro", a aceleração econômica dos anos 1968-1974,

incluindo os estudos sobre o irrisório das condições salariais, produzidos pelo DIEESE. ${ }^{6}$

Completa nossos estudos a longa parceria com o professor José de Souza Martins, desde os anos 1980, na leitura das obras de Karl Marx e Henri Lefebvre, partilhadas com novos pesquisadores da História, Sociologia, Antropologia, Pedagogia, Arquitetura da USP e de outros campi.

Nos anos 1990, passamos a nos dedicar ao Laboratório de Geografia Urbana - LABUR através de grupos de formação acadêmica e extensão universitária, envolvendo, entre outras leituras, as de Marx e Lefebvre; mais recentemente (a partir dos anos 1990), a de situacionistas, incluindo Guy Debord e Raoul Vaneigem, na direção do necessário debate sobre a produção do espaço e a reprodução social crítica; e textos clássicos sobre a

\footnotetext{
3 HARVEY, David. A Justiça Social e a cidade. São Paulo: Hucitec, 1980. Mais especificamente, lembro-me do manuscrito do capítulo 5, Valor de uso, Valor de troca e a Teoria do uso do solo urbano.

${ }^{4}$ QUAINI, Massimo. Marxismo e Geografia. Rio de Janeiro: Paz e Terra, 1979 e BERTANINI, Tonino.

O "Espaço do Corpo" e os Territórios da Vida Cotidiana, Seleção de Textos. São Paulo: AGB-SP, junho de 1985, n.o 10. Este último texto, com revisão técnica da tradução por Moacyr Marques.

${ }^{5}$ Incluindo chapas concorrentes ao DCE livre Alexandre Vanucchi Leme, criado em 1976.

${ }^{6}$ Departamento Intersindical de Estatística e Estudos Sócio-econômicos.
} 
formação brasileira, de Antonio Cândido, Sergio Buarque de Holanda, e outros não geógrafos ou geógrafos. ${ }^{7}$

Com o tempo, nos Simpósios de Geografia Urbana (SIMPURB), acabamos por representar a tendência teórico-metodológica designada como marxista-lefebvriana. Cabe perfeitamente esta designação. Os estudos lefebvrianos, envolvendo o urbano, do LABUR, tenderam a se ampliar e, hoje, nosso trajeto se soma a inúmeros outros na mesma direção, em outros estados e com vários outros pesquisadores.

Esse nosso trajeto acabou por nos aproximar dos lefebvrianos europeus, especialmente, os franceses, reunidos na Association La Somme et Le Reste, criada nos anos 1990, após a morte de Henri Lefebvre, com vistas a resgatar a obra de Lefebvre e atualizar seu aporte, através de novos pesquisadores. Dela nasceu a Revue La Somme et le Reste, na qual colaboramos. ${ }^{8}$

\section{Para o método, a negatividade como fundamento ${ }^{9}$}

\section{Falamos da modernidade.}

O que falamos dela: ela é cisão ao nível do natural e do social; a natureza decifrada e dividida para servir como matéria prima, como meio de produção, como força natural produtiva; a sociedade dividida entre os que produzem e os que consomem, no sentido de uns consumidos, outros consumidores; a força social produtiva do trabalho como força produtiva do capital. Na prática e na teoria, será preciso romper com a exterioridade recíproca de tudo o que é natural e social; a separação dos elementos constitutivos da totalidade, própria da modernidade. Contudo, esta exterioridade e exteriorização - como processo - são reais, não inventadas, imaginadas. Pode-se, também, definir por estranhamento; existindo como alienação necessária. O ponto nodal de outro caminho, que não essa positividade dilaceradora, é a negatividade como fundamento. A crítica da

\footnotetext{
${ }^{7}$ As parcerias dizem respeito aos integrantes do LABUR e além dele: Odette Carvalho de Lima Seabra, Ana Fani Alessandri Carlos, Margarida Maria de Andrade, Sandra Lencioni, Jorge Hajime Oseki, Ana Cristina Nasser, Luciano Marini, entre outras. Desdobrando-se nos anos de orientação, que ampliaram e ampliam substancialmente nosso diálogo, com jovens pesquisadores.

${ }^{8}$ Somos redatoras-correspondentes da Revue La Somme et le Reste. Études Lefebvriennes-Réseau Mondial. Paris, França, a partir de 2002. Para citar este trajeto em seu início:

"Présentation du Programme d'Études sur Henri Lefebvre au Labur - Laboratoire de Géographie Urbaine", veiculado por Internet, no Colloque "Centenaire d'Henri Lefebvre", em 14/junho/2001, envoi n.o 14. E "Présentation du programme d'Études sur Henri Lefebvre au LABUR (Laboratoire de Géographie Urbaine) - Brésil", Revue La Somme et le Reste - Études Lefebvriennes - Réseau Mondial, difundida por Internet, penseelefebvre@aol.com, no 1, outubro 2002, pp. 6-7.

${ }^{9}$ O presente texto baseia-se em DAMIANI, Amélia Luisa. Espaço e Geografia: Observações de Método. Elementos da obra de Henri Lefebvre e a Geografia. Ensaio sobre Geografia Urbana a partir da Metrópole de São Paulo, 2008, Prefácio e Introdução.
} 
modernidade é a negação mais radical do que existe: a negação, como sujeito. Isto é, "[0

homem] como um movimento que é impossível isolar no seio da totalidade." ${ }^{10}$

O ambiente da modernidade destaca no homem a liberdade, a historicidade e a individualidade, vividas negativamente.

"O trabalho não como objeto, mas como atividade; não como autovalor, mas como fonte viva do valor. A riqueza universal, com respeito ao capital, na qual existe objetivamente, como realidade, como possibilidade universal do mesmo, possibilidade que se preserva na ação enquanto tal. Não é em absoluto uma contradição afirmar pois que o trabalho por um lado é a miséria absoluta como objeto, e por outro é a possibilidade universal da riqueza como sujeito e como atividade $[. . .]^{11}$

"No conjunto da sociedade burguesa atual, esta redução a preços e a sua circulação, etc., aparece como o processo superficial sob o qual, entretanto, ocorrem, em profundidade, processos completamente diferentes, nos quais aquela igualdade e liberdade aparentes dos indivíduos se desvanecem. Por um lado, se esquece desde um princípio que o suposto do valor de troca, enquanto base objetiva do sistema produtivo em seu conjunto, já inclui em si a coerção ao indivíduo; que o produto direto deste não é um produto para ele, pois só chega a sê-lo através do processo social e tem que adotar essa forma geral ainda exterior; que o indivíduo só existe enquanto produtor de valor de troca, o que implica a negação absoluta de sua existência natural; o indivíduo, pois, está completamente determinado pela sociedade. ${ }^{12}$

"E não é ademais, como uma pedra, um dado imóvel, [o homem] leva consigo a Negatividade; e a força, a violência da negatividade o projetam dentro do movimento incessante da história, que o modifica, e que unicamente através do tempo realiza a totalidade do real concreto." ${ }^{13}$

A importância materialista da forma vazia se coloca precisamente. Não se manter no plano dos conteúdos, imediatamente, mas produzir um pensamento a partir da forma pura, vazia. Ela, livre de qualquer conteúdo (aparentemente), coloca a possibilidade de um pensamento sobre todos os conteúdos, sem eleição de alguns, em detrimento de outros. Os valores limitados de uma época, uma escolha arbitrária a partir deles é corrigida por esse começo abstrato e vazio: a forma pura. É um legado da filosofia, pensá-la assim, na busca filosófica da verdade. Hegel deu uma enorme contribuição: a morte do homem, o eu pessoal puro... "como uma intimidade na exterioridade dessas coisas que são em si"14

A lógica que privilegia a forma pura e a partir dela deriva o mundo dos conteúdos coloca-se como a possibilidade mais radical da crítica, pois revela, potencialmente, o dilaceramento da modernidade. Quantos desdobramentos, Henri LEFEBVRE realizou, a partir dessa concepção!

\footnotetext{
${ }^{10}$ BATAILLE, Georges. Escritos sobre Hegel. Madri: Arena, 2005, p. 14.

${ }^{11}$ MARX, Karl. Elementos Fundamentales para la Crítica de la Economia Política (Grundrisse) 1857-1858, 1977, volumes 1, MARX, Karl. Elementos Fundamentales para la Crítica de la Economia Política (Grundrisse) 1857-1858. México: Siglo Veintiuno, 1977, volumes 1, p. 236.

${ }^{12}$ Op. cit., p. 186.

${ }^{13}$ BATAILLE, Georges. Escritos sobre Hegel, 2005, p. 15.

${ }^{14}$ Op. cit., p. 12.
} 
Indo da forma mais abstrata às mais concretas, mas jamais negando, metodologicamente, a potência de um pensamento que as tenha como seu começo ${ }^{15}$; pois, assim, busca se libertar de representações naturais e sociais que paralisam a crítica antes da busca de seu fundamento. A dialética da forma e do conteúdo é o princípio. Então, este árduo caminho que vamos trilhar, vulgarizado, pois é o modo possível de sua exposição no contexto posto, mantém este princípio: o da crítica radical que tem por necessidade considerar a dialética da forma e do conteúdo. E alguns de seus elementos apresentamos agora.

"[...] um Mundo histórico, onde a Negatividade do homem, esse Nada que o rói por dentro, cria o conjunto do real concreto (ao mesmo tempo objeto e sujeito, mundo real transformado ou não, homem que pensa e muda o mundo)."16

\section{A dialética da forma e do conteúdo mantém o negativo como interno e em} movimento.

\section{Henri Lefebvre e a Geografia}

Nossa busca, que não tem um centro duro na Geografia, também é consciente. Trata-se de uma aproximação disciplinar, a partir das periferias de uma ciência em particular, neste caso, a Geografia. A lógica implicada é que deste ângulo se abririam possibilidades de compreensão sobre o objeto da Geografia, agora numa direção mais abstrata e teórica. Um eixo imanente a este ponto de vista, a propósito da Geografia, seria a virtualidade de uma teoria geográfica do espaço, a partir da qual, negativa e positivamente, podemos chegar à produção do espaço, concepção que não cabe reduzidamente numa disciplina científica, mas a atravessa, diante de suas possibilidades categoriais. Duas influências devem ser ressaltadas neste sentido: a de Henri LEFEBVRE e a de Karl MARX. O primeiro por propor, dentro do marxismo, a inerência da categoria de produção do espaço num pensamento sobre a formação econômico-social capitalista, produzindo uma revisão do que poderia ser definido como uma noção abstrata e matemática do espaço (como categoria filosófica do ser e de sua determinação no mundo, enquanto tal). Sua influência na Geografia é evidente. ${ }^{17} \mathrm{Em}$

\footnotetext{
${ }^{15}$ Quase impossível indicar um livro seu, somente. Mas, vejamos, alguns fundamentais: A la lumière du Matérialisme Dialectique - 1. Logique formelle, logique dialectique, 1947 (sobre o movimento das formas, através da lógica formal e da lógica dialética ); La Révolution Urbaine, 1970 (sobre a forma urbana) ; La vie quotidienne dans le monde moderne, 1968 (sobre a grade da forma pura às mais concretas); Au-delà du structuralisme, 1971 (sobre a relação dialética entre forma e conteúdo) ...

${ }^{16}$ BATAILLE, Georges. Escritos sobre Hegel, 2005, p. 13.

${ }^{17}$ Apenas para citar alguns autores - além da presença uspiana, da presente autora e, expressamente, das professoras Ana Fani Alessandri CARLOS, Odette Carvalho de Lima SEABRA e Margarida Maria de ANDRADE, com relação à aproximação de LEFEBVRE e a Geografia, todas nós ligadas, atualmente, ao grupo de resgate de sua obra da Revista La Somme et le Reste - études lefebvriennes - réseau mondial, lembremos de GOTTDIENER, Mark. A produção social do espaço urbano, 1993; SMITH, Neil. Desenvolvimento desigual, 1988; SOJA Edward. Geografias pós-modernas, 1993; e HARVEY, David. Condição pós-moderna, 1992 e El nuevo imperialismo, 2004 ; entre outros.
} 
sua obra, há a superação da ciência do espaço - lógico-formal - pela categoria de produção do espaço - mais dialética e, assim, mais concreta -. Poderíamos situar, dentro do pensamento geográfico, como momentos importantes destas concepções, respectivamente, o da Geografia teorética e aquele da Geografia crítica; o primeiro, aproximando-se de uma ciência abstrata do espaço, como arcabouço sistematizador de conteúdos empíricos - por si sós a serem superados, em prol de um paradigma científico e universal -; e o segundo, de influência marxista. ${ }^{18}$ A propósito de Karl MARX, a crítica à economia política é o fundamento de uma crítica social possível, sem receio de parar o movimento de um pensamento materialista concreto e dialético. ${ }^{19}$ Ainda, a ressaltar, que se tem por objetivo, sem reduções economicistas, ou exclusivos econômicos, fazer conscientemente Geografia sem desprezar a potência da determinação econômica, na sociedade contemporânea, e a totalidade social, para a qual ela se abre. ${ }^{20}$

Assim, há um projeto de reconstituição de método, para situar e, assim, compreender a categoria espaço no processo social contemporâneo; incluindo o significado da inversão metodológica e teórica do suporte lógico-espacial, no âmbito da ciência do espaço, em produção do espaço para os estudos geográficos. E, através da produção do espaço, chegar à concepção de uma crítica à economia política do espaço e o lugar da Geografia na crítica social.

Da mesma maneira que uma lógica do espaço, embora superada por um conhecimento concreto do espaço, preserva-se, de algum modo, mesmo contendo seu outro: o raciocínio abstrato das formas espaciais - redes e tramas; eixos; pontos; superfície e profundidade; conjunções e disjunções; ramificações e hierarquias; nexos e separações; fluxos e contornos definidos e fechados; fronteiras ... ${ }^{2}{ }^{21}$, uma antropologia, vinculada ao espaço, contendo um cunho ontológico, define genericamente a relação homem-natureza e convive,

\footnotetext{
${ }^{18}$ Indico aqui, entre os inúmeros trabalhos, três deles: o primeiro, reunindo a concepção teorética - CHORLEY, Richard J. e HAGGETT, Peter (orgs.). Modelos integrados em Geografia, 1974 -; o segundo, influenciando, decisivamente, a Geografia marxista - LIPIETZ, Alain. Le capital et son espace, 1977 -; e o terceiro, sintetizando as concepções em Geografia, a partir da Geografia Regional: LENCIONI, Sandra. Região e Geografia, 1999.

${ }^{19}$ MARX, Karl. Teses sobre Feuerbach. IN: Karl Marx e Friedrich Engels - Textos. São Paulo: Edições Sociais, 1977, volume I, p. 118-120.

${ }^{20}$ Meus anos de estudo da obra de MARX e a visita frequente a seus escritos, nos grupos de orientação do LABUR - instrução sempre incompleta e aberta - dão a referência primordial de meu modo de fazer Geografia e o necessário fundamento para compreender LEFEBVRE e o vínculo constituído com a obra dos situacionistas, destacando-se os autores Guy DEBORD e Raoul VANEIGEM. Entre os geógrafos marxistas, Neil SMITH e David HARVEY, com quem o diálogo em Geografia é imprescindível, especialmente quando se trata de Geografia Urbana.

21 "[...] Fora das coisas, o espaço tomado como forma aparece neste sentido como substância (espaço cartesiano) ou ao contrário como 'puro a priori' (Kant)." (LEFEBVRE, Henri, La production de l'espace. Paris: Anthropos, 2000, 4.a edição. p. 251)
} 
contraditoriamente, com uma sociologia do espaço e uma história do espaço, em que o peso e a pressão da história são desumanizadores, numa formação histórico-social particular. ${ }^{22}$

Uma geografia estruturalista se aproxima dessa lógica espacial; assim como, uma geografia humanística renova a geografia clássica, mantendo a relação de identidade positiva e humanizadora entre o homem e seu espaço. Na verdade, é possível aproximar ambas as geografias, considerando as formas de orientação, dispersão e interdição, como modos de ocupação e simbolização dos espaços humanizados. ${ }^{23}$ Essas inerências do espaço e do homem são postas num movimento universal e particular por uma concepção dialética do espaço.

A presente proposta guarda o objetivo de localizar essas tendências metodológicas, aprofundando alguns de seus instrumentos de compreensão.

MERLEAU-PONTY advoga a impossibilidade da separação entre espaço e corpo. Resolve essa equação numa ontologia imersa na ambiguidade, ou oscilação, entre espaço e corpo. Condizente com a tradição leibniziana, o corpo é espacial e não existe, rigorosamente, espaço em si. Este argumento, a partir de LEIBNIZ, é recuperado por Henri LEFEBVRE em La production de l'espace. ${ }^{24}$ Há entre nós, geógrafos, uma concepção em curso que é a de desconsiderar o espaço como simples continente vazio. Ou, melhor, considerar o espaço como elemento ativo do processo social. Desta forma, vamos em direção a pensar o espaço e o corpo conjuntamente, numa simbiose positiva e identitária e, ao mesmo tempo, incluindo um processo de identificação negativo. O espaço prenhe de relações sociais, como prática espacial. Chega-se, por esta via, à negação de uma noção fetichizada do espaço e, em prol de destituir essa coisificação, resolve-se o espaço em relações, relações entre os indivíduos, relações sociais, as relações sociais como sócioespaciais, como prática espacial. Contudo, esta forma mais complexa de conceituar o espaço não é exata e, estritamente, um fato presente a constatar. É e pode ou deve ser o projeto, a possibilidade. Há, na verdade, um esgarçamento das relações sócioespaciais, conteúdo de um espaço produzido para compra e venda, não para o viver. O espaço prático-sensível, aquele da ocupação do espaço por um corpo espacial, é contradito pelo espaço específico, prático-social, produzido por

\footnotetext{
${ }^{22} \mathrm{Na}$ direção do imperativo histórico das abstrações concretas, formula-se a hipótese extrema da mercadoria ocupando o espaço inteiro. (Op. cit. p. 253) A este propósito, é magistral e imprescindível a concepção de Guy DEBORD (La société du spectacle, 1992).

${ }^{23}$ Incluindo a passagem do espaço real vivido ao espaço percebido, simbolizado. (LEFEBVRE, Henri, La production de l'espace, 2000, capítulo III)

${ }^{24}$ 2000, 4. a edição, capítulo III, p. 197-263. E ainda, entre outros, os livros de David HARVEY: Condição Pós-moderna, 1992, sobre o espaço relacional e o livro Justice, Nature and the Geography of Difference,1999, aprofundando e retomando esta influência.
} 
forças produtivas sociais e sujeito aos limites das relações de produção, incluindo as ideologias. $^{25}$

O que se põe, desviando a fenomenologia implicada na concepção de MERLEAU-PONTY, é o trabalho do negativo na noção de espacialidade, na relação espaço-corpo. Como fundamento último e histórico da formação da sociedade moderna e da relação antitética entre espaço-corpo, define-se a violência de pôr o homem a trabalhar, de produzir a identidade do homem através do trabalho, o que inclui a expropriação do $\operatorname{corpo}^{26} \mathrm{~A}$ alienação do trabalho seria uma mediação necessária na implicação espaço-corpo. Por que espaço-corpo? Seria uma biologização dos termos? Por que não espaço e linguagem, o homem, ser consciente, que reflete sobre suas práticas, nomeia-as? Porque o corpo seria a última resistência, a mais íntima, a um processo de exteriorização, que é, ao mesmo tempo, de estranhamento. ${ }^{27}$ Situa-se, assim, o tratamento da percepção, do sensível, ao nível do método.

O mais externo é, ao mesmo tempo, o mais interno ${ }^{28}$, inclusive sem os recursos da manipulação pela linguagem, como construção racional do discurso. O estranhamento é interiorizado como negação sensível do sujeito autônomo e livre e se torna simbiose e reflexo, esquizofrênico e terrorista, da presença do Outro diante do sujeito ausente, negado em sua possibilidade de ser. Entre o interno e o externo, o real e as representações - dos símbolos às ideologias -, a coexistência no espaço e a sucessão no tempo ${ }^{29}$, o corpo e o espaço, há mutualidade, produzindo identidades e separações historicamente situadas.

"[...] Para Leibniz, espaço e tempo não eram reais ou materiais ou mesmo ideais em si mesmos, mas admitem uma existência 'secundária' ou 'contingente' [...] derivativa inteiramente das substâncias e processos neles contidos." ${ }^{30}$

David HARVEY contrapõe o modo relacional da concepção leibniziana de espaço à teoria do espaço absoluto de Newton, que teria prevalecido na história do capitalismo moderno, sendo a primeira concepção própria de caminhos de pensamento medieval e pré-capitalista, embora não tenha jamais desaparecido: multiplicidade de perspectivas espaço-temporais de

\footnotetext{
${ }^{25}$ O plano é o da compenetração dos espaços sociais. (LEFEBVRE, Henri, La production de l'espace, 2000, p. 242-244) Ainda que de passagem, é interessante situar o esforço de David HARVEY na organização de uma grade imbricada de práticas espaciais. IN: Condição pós-moderna, 1992, parte III, A experiência do espaço e do tempo, capítulo 13, Espaços e tempos individuais na vida social, p. 203.

26 "[...] o que realmente está em jogo é a disciplina exigida pelo trabalho industrial: a expropriação do corpo, literalmente, ou seja, a organização prática da ausência e o preenchimento do enorme vazio por representações morais, religiosas, políticas [...] o trabalho como liberdade." (LEFEBVRE, Henri. La presencia y la ausencia, 1983, p. 179)

27 "A destruição do espontâneo e do natural - portanto do uso - não se realiza somente na natureza exterior, mas também na natureza interna do ser humano, o corpo, o sexo". (LEFEBVRE, Henri. La presencia y la ausencia, 1983, p.185)

${ }^{28}$ Reiteradamente, aparece o fundamento hegeliano desta concepção.

${ }^{29}$ Ir ao nível da prática espacial equivale a chegar aos conteúdos da vida individual e social, a partir de suas contingências espaçotemporais; sendo que esse duplo espaço-tempo reúne o coexistente e o sucessivo, numa grade complexa de realidade e representação.

${ }^{30}$ HARVEY, David. Justice, nature and the geography of difference, 1999, p.251.
} 
um único universo (a ideia de situação - ou, mais precisamente, situacionalidade -; posição ou posicionalidade -; e condição); individualização de um espaço através de mútuas relações e conexões implicadas; e múltiplas estruturas espaciais possíveis, como inerentes a atividades e práticas sociais e como construções lógicas, que, secularizadas, incluiriam uma abordagem sobre o devir; estas estariam entre as virtudes da abordagem leibniziana. ${ }^{31} \mathrm{~A}$ atualidade da concepção está em mobilizar os termos da relação espaço-corpo, relativizá-los mutuamente, de maneira que o espaço puro e vazio só pode ser a ausência do corpo e das práticas sociais, não sua universalidade. ${ }^{32}$

No seu fundamento econômico, o comprometimento e o esvaziamento de práticas espaciais, como inerentes à nossa economia, se resolvem na violência da produção do vazio. A produção do vazio se põe como negação da realidade das práticas sócio-espaciais. ${ }^{33}$

Como uma descontinuidade demarcatória e necessária nos estudos geográficos, incluindo a categoria espaço, na sua particularidade - determinada pela formação econômico-social capitalista - está a potência, prática e teórica, da abstração, em outros termos, a realidade das abstrações concretas, que se põem no vivido, nas relações reais, inclusive sensíveis; a força da abstração, das relações abstratas, definindo a história e o espaço contemporâneos. Henri LEFEBVRE conceitua como espaço abstrato, onde as particularidades naturais do espaço e do corpo vão se esvaindo. Se elas aparecem, na modernidade, são como realidade histórico-poética, que se liga ao folclore, como espaços de representação com áurea de familiar, mas, na verdade, enigmáticos, o que, aliás, os torna manipulados como ideologia, como espetáculo e seus negócios, mais facilmente. ${ }^{34}$

"E eis um primeiro aspecto, o mais simples, desta história do espaço que vai da natureza à abstração. Que se imagine o tempo em que cada população conseguiu medir o espaço, tendo suas unidades de medida, emprestadas de partes do corpo: polegar, cotovelo, pé, palmo, etc. [...] A relação do corpo com o espaço, relação social de uma importância desconhecida em seguida, conservava então uma imediaticidade que deveria se alterar e se perder: o espaço, a maneira de o medir e de falar dele apresentavam aos membros da sociedade uma imagem e um espelho vivo de seu corpo [...] As flutuações da medida e por conseqüência das representações do espaço acompanham a história geral Ihe conferindo um certo sentido: a tendência ao quantitativo, ao homogêneo, à desaparição do corpo que busca refúgio na arte." 35

\footnotetext{
${ }^{31}$ Op. cit., capítulo 10.

${ }^{32}$ Trata-se de uma releitura de Leibniz, desviando e secularizando sua concepção.

${ }^{33} \mathrm{O}$ conceito vislumbrado é o da acumulação primitiva do espaço.

${ }^{34}$ LEFEBVRE, Henri, La production de l'espace, 2000.

${ }^{35}$ Op. cit., p. 131. Ver, também, SILVA, Ana Cristina Mota. A constituição da cidade como negócio. Os termos da urbanização de Fortaleza: 1830-1866, 2003.
} 
O espectro metodológico deste trabalho vai ganhando abrangência indo do plano estrutural

- localizando as estabilidades e os processos sociais - ao nível do sensível e seu rebatimento percebido: a "vivência" da inversão do material em formal, do uso na abstração da troca, própria dos tempos modernos.

Ainda citando LEFEBVRE, a alienação tem um estatuto social na obra de MARX, o conceito de produção de mais-valia entra no domínio do saber e se realiza na vida cotidiana, e é identificado pelos trabalhadores, como humilhação, opressão, que são modos percebidos dos fundamentos da exploração.

“À sua maneira, Marx revelou, nas condições práticas, no 'vivido', uma tríade desconhecida: exploração, opressão, humilhação. Estes três termos vêm juntos, sem se confundirem. Participam da denotação e da conotação de um único termo: a alienação [...] ninguém está disposto a morrer defendendo ou atacando o conceito de mais-valia, enquanto que inumeráveis seres humanos combateram e combatem ainda contra a humilhação e a opressão, através das quais vivem a exploração." ${ }^{\prime 36}$

A plasticidade de como o conceito se põe na realidade é argumento reiterado de HARVEY para localizar a dialética entre o processo abstrato do capital, enquanto potente, na subsunção das diferenças corporais ${ }^{37}$, culturais $^{38}$, geográficas e históricas ${ }^{39}$ e, ao mesmo tempo, considerar essas diferenças como sugestivas da "reconstrução de maneiras distintivamente capitalistas". ${ }^{40}$ Não se trata de distinções empíricas, mas de formas de realização do conceito. A busca, no reconhecimento das diferenças, é a da formação da classe para si, do trabalhador como agente político, do corpo como lócus de resistência política e não estritamente a das adequações diversas ao capital ${ }^{41}$, incluindo a dialética da política no movimento das micro e macro escalas geográficas. ${ }^{42}$

Da produção do espaço às práticas espaciais - do plano estrutural ao cotidiano - esses instrumentos conceituais podem servir a um conhecimento geográfico inserido na crítica social.

\footnotetext{
${ }^{36}$ LEFEBVRE, Henri. Hegel, Marx, Nietzsche, 1988, p. 128-129.

${ }^{37}$ A partir de MARX, retoma a distinção entre o trabalhador como pessoa, corpo, vontade e a força de trabalho propriamente, sendo o hiato entre ambos o nexo da alienação; distingue o corpo de cada trabalhador e a força de trabalho como um todo: "o 'corpo coletivo" da força de trabalho, decomposto em hierarquias de aptidões, de autoridade, de funções mentais e manuais etc. de modo que torna internamente heterogênea a categoria de capital variável." (HARVEY, David. Espaços de esperança, 2004, capítulo 6; citação, p. 142 e 144)

${ }^{38}$ Não definidas como categorias essencialistas, mas compreendidas como construções sociais. (Op. cit., p. 146)

39 "O valor é uma construção espaço-temporal distintiva que depende do desenvolvimento de toda uma gama de práticas espaçotemporais ..." - territorialização dos direitos de propriedade e de Estados; redes geográficas para circulação do dinheiro e demais mercadorias; incluindo, processos de circulação em escalas espaço-temporais diferentes (entre elas, a translação entre a escala da "globalização", definida pela longa geografia histórica da acumulação do capital e a da produção e reprodução do corpo trabalhador num espaço mais restrito)... -. (Op. cit., p. 149 e 150)

${ }^{40}$ Op. cit. p. 146. Ver parte 2 - Dos corpos e das pessoas políticas no espaço global (HARVEY, David. Espaços de esperança, 2004).

${ }^{41}$ HARVEY, David. Espaços de esperança, 2004, capítulo 7, p. 161-178.

${ }^{42}$ Op. cit., capítulo 3, p. 63-77.
} 
A premissa é a da relação entre o homem e a natureza e entre os homens, enquanto fundamento da prática sócio-espacial. Sendo que a natureza, natureza natural e produzida, é definida como essencialmente social. ${ }^{43}$ Produto da história humana, a natureza é concebida como incluindo internamente um processo de objetivação do homem ${ }^{44}$, que é, ao mesmo tempo, um processo de subjetivação; este, por sua vez, se desdobra em estranhamento e apropriação individual e social. Assim, a exterioridade da natureza, em relação ao homem, ao invés de ser inerente e a definir como um universal em si, é passível de ser concebida somente como produto da relação, num processo histórico contraditório à humanização da natureza e à naturalização do homem. ${ }^{45}$

Do ponto de vista do conhecimento, é possível e necessária a análise da natureza e do homem, segmentando seus conteúdos: físicos, químicos, biológicos, humanos, sociais..., mas, neste movimento, que inclui o desenvolvimento de ciências parcelares e seus objetos de estudo, identifica-se um movimento do "abstrato ao concreto"; sendo seus aspectos físico-naturais momentos mais "abstratos", incorporados, e desse modo metamorfoseados, pelos conteúdos sociais mais concretos; compreendendo-se que uns incluem aos outros, num processo dialético de incorporação. Certamente, assim, se busca superar uma concepção positivista do desenvolvimento das ciências, que trata a cada uma, no limite último, como campo fechado de conhecimento e não comporta esses nexos científicos dialéticos, decorrentes dos limites respectivos de cada ciência em particular. ${ }^{46}$ Por outro lado, dados os termos da prática científica em curso, cujo fundamento é a necessidade científica e técnica da separação, sob a representação de uma unidade, considera-se a dificuldade do transdisciplinar, como superação das ciências em particular, enquanto núcleos duros de conhecimento.

Henri LEFEBVRE situa, no final do século XIX, uma negação do positivismo, na sua própria constituição, no sentido de que ele representava pouco os avanços científicos de seu tempo, avanços que punham a possibilidade do desenvolvimento da ciência teórica, movida por

\footnotetext{
${ }^{43}$ Pretende-se superar a visão de uma natureza natural como um universal, com a biologia, como seu núcleo vital, contendo a natureza humana apenas como subconjunto, historicamente contingente. Assim como, o princípio do espaço absoluto, como elemento da natureza dessa forma definida, também, tido como universal, infinito e imutável, recebendo os eventos materiais, mas não se alterando substantivamente. O nexo entre o universal, a contingência e o particular é interno e se há qualquer grau de exterioridade posto, ele é produzido. A natureza não é concebida como exterior à sociedade, primitiva e pré-humana. (SMITH, Neil. Desenvolvimento desigual natureza, capital e a produção de espaço, 1988).

44 “Escrevendo na metade do século XIX, Karl Marx explicitamente tentou uma reconciliação analítica da natureza e da história e estava claramente consciente da significação ideológica da natureza universal [...] Marx insistia vigorosamente sobre a unidade da natureza e da História, chegando até mesmo a sugerir em sua época que virtualmente não existia mais nenhuma natureza que tenha precedido a história humana". (Op. cit. p. 48)

${ }^{45}$ MARX, Karl. Manuscritos Econômico-filosóficos - Terceiro manuscrito. IN: MARX - Os Pensadores, 1978.

${ }^{46}$ Aqui reaparece a ideia de periferia de uma ciência parcelar específica. Quando seu próprio objeto propõe a incorporação de outra ciência, pois ele é parte de um processo real e de conhecimento, cuja noção de totalidade exige esses nexos científicos.
} 
hipóteses teóricas, de caráter relativo, expressando "a possibilidade de uma revisão e de um aprofundamento dos conceitos", que incluía, na constituição das ciências, uma relação interna entre elas. ${ }^{47}$ Ele avaliava a Geografia contendo internamente esta possibilidade. ${ }^{48}$

Não haveria fronteiras estanques e rígidas entre as ciências, como advogava o positivismo, mas linhas de demarcação flexíveis. "Portanto, as ciências tenderiam à unidade [...], que se faz por um movimento interno." 49 "Entre as ciências do homem e aquelas da natureza se intercala a geografia humana". ${ }^{50}$

Ao mesmo tempo, cada vez mais, com o desenvolvimento científico, e a prática social, que define suas condições, cada parte ínfima de um todo constitui uma totalidade complexa, em si mesma. Na escala dessa parte, ela pode aparecer como um sistema, um todo estruturado; noutra escala ela se resolve numa rede de relações mais global. ${ }^{51}$

“A partir da física quântica, um princípio fundamental norteador é que 'o que quer que você diga de uma coisa ou estrutura que ela seja, ela não o é' porque 'há sempre algo mais do que você disse e algo diferente' $[. . .]^{\prime \prime 52}$

Toda categoria fixa é capaz de dissolução. O que é composto pode se dividir, sendo que "a decomposição abre novos domínios e campos de investigação e prática." ${ }^{53}$

“[E] se todas as 'coisas' são heterogêneas em virtude de processos complexos (ou relações), que as constituem, então, a única forma de compreender qualitativa e quantitativamente os atributos das 'coisas' é pela compreensão dos processos e relações que lhes são internos."

Entre as ciências e a partir de cada ciência, no âmbito das categorias do conhecimento, produzem-se novos campos de conhecimento, movidos por relações de interioridade implicadas.

Da Geografia, como seu mérito e sua partilha interna, derivaram além de cisões metodológicas, a multiplicação de especializações, de conteúdos programáticos, que comprometiam sua unidade disciplinar. Sobre a tentativa de unidade disciplinar, é importante destacar a mediação da Geografia Regional, que, por algum tempo, se realizou amplamente. ${ }^{55}$ Sobre a crise das subdivisões internas à Geografia, a ponto de se pensar na

\footnotetext{
${ }^{47}$ LEFEBVRE, Henri. Méthodologie des sciences, 2002, p. 47.

48 Localizando esta contribuição de Lefebvre, ver: DAMIANI, Amélia Luisa. A Geografia que desejamos. Boletim Paulista de Geografia. São Paulo: AGB-SP, 2005, n.o 83, p. 57-90.

${ }^{49}$ LEFEBVRE, Henri. Méthodologie des sciences, 2002, p. 48

${ }^{50}$ Op. Cit., p. 51.

${ }^{51}$ HARVEY, David. Justice, nature and the geography of difference, 1999, p. 51-52.

52 Op. cit., p. 52.

${ }^{53}$ Op. cit., p. 52.

${ }^{54}$ Op. cit., p. 52

${ }^{55}$ LENCIONI, Sandra. Região e Geografia, 1999, capítulo 2: A Geografia como ciência e a região como objeto de estudo, p. 73-118.
} 
sua autodestruição científica, cabe considerar a linha demarcatória que representa o livro $A$ Geografia Ativa, escrito no início dos anos 1960, por geógrafos reunidos em torno de Pierre GEORGE. ${ }^{56}$ A via das especializações atravessa a Geografia, nela as especializações são definidas como estreitas: "sacrifica-se a cultura sintética do geógrafo". A concepção norteadora do livro indicado é a de situação, como geografia regional dinâmica.

\begin{abstract}
"Este espaço geográfico aparece assim não somente como um espaço humanizado, mas como um espaço relativizado, que se amolda em função das técnicas, das estruturas econômicas e sociais, dos sistemas de relações. 0 próprio espaço torna-se situação." ${ }^{57}$
\end{abstract}

A Geografia, o tempo todo, está incluída neste possível-impossível ${ }^{58}$ de relacionar fenômenos de natureza tão diversos. Uma Geografia sistêmica conduziu os estudos de Geografia Física e uma Geografia Crítica refletiu a Geografia Humana que estudava os fenômenos modernos e sociais. No primeiro caso, a noção de geossistemas ${ }^{59}$ demarca estudos em Geografia Física; no segundo caso, no interior da Geografia Humana, chegou a prevalecer a influência marxista e através dela desde a noção de valorização do espaço ${ }^{60}$ até a inclusão da possibilidade de se pensar em uma dialética espacial ${ }^{61}{ }^{62}$

Dialetizar o acervo conceitual da Geografia, diante dessas diferenças, seria uma tarefa bastante complexa, apenas se situa aqui o liame e, ao mesmo tempo, a divisão que a constitui internamente. A noção de natureza, interna ao processo social, estabelecida como pressuposto, não esgota o caráter aporético intrínseco à Geografia, que vai das estruturas técnicas que contém - como a cartografia geográfica e suas recentes promoções tecnológicas, com o geoprocessamento - às suas divisões disciplinares analíticas - muitas ligadas às ciências da natureza, como pedologia, geomorfologia, climatologia, embora não o sejam, estritamente -. Mas, define-se uma linha de continuidade, apesar das descontinuidades temáticas e metodológicas da Geografia, que se impõem cotidianamente

\footnotetext{
${ }^{56}$ GEORGE, Pierre; GUGLIEMO, Raymond; LACOSTE, Yves e KAYSER, Bernard. A Geografia Ativa, 1966.

${ }^{57}$ Op. cit., p. 26

58 "A dialética do possível [...] traz a chave para abrir as portas fechadas do presente. O possível se opõe ao real e faz parte do real: de seu movimento [...] A alienação toma o máximo de intensidade e diversidade no momento em que a maior 'desalienação' se aproxima; o que torna necessária a consciência a mais aguda de todas as formas de alienação, para recusá-las [...] O novo romantismo (revolucionário) afirma o primado do possível-impossível e compreende esta virtualidade como essencial ao presente. Ele estima assim transpor o abismo entre o vivido parcial e o presente total." (LEFEBVRE, Henri. Au-delà du structuralisme, 1971, p. 48-49)

${ }^{59}$ MONTEIRO, Carlos Augusto de Figueiredo. Geossistemas - a história de uma procura, 2000.

${ }^{60}$ Entre os autores: MORAES, Antonio Carlos e COSTA, Wanderley Messias. A valorização do espaço, 1984.

${ }^{61}$ Entre os autores: SOJA, Edward. Geografias Pós-Modernas - A Reafirmação do Espaço na Teoria Social Crítica, 1993; CARLOS, Ana Fani Alessandri; DAMIANI, Amélia Luisa; SEABRA, Odette Carvalho de Lima (Orgs.). O espaço no fim de século: a nova raridade, 1999.

${ }^{62}$ Esta partilha, jamais, foi superada. A crise ecológica atual, os instrumentos técnicos à disposição do geógrafo, as formas de profissionalização propostas por nossa época definem praticamente um segmento da Geografia, cindido do outro. Surge como necessidade e dificuldade um conhecimento sobre a determinação da crise econômico-social.
} 
no próprio processo de aprendizado desta ciência: a Geografia tem como fundamento próprio a Geografia Humana. Ela Ihe define a noção de totalidade. Trata-se, deste modo, de uma ciência social.

Estabelecendo uma tentativa de dialetização do projeto científico da Geografia, no sentido mais amplo, imobilizando suas diferenças analíticas e metodológicas mais específicas, é possível reconhecer como ponto de ruptura a passagem da perspectiva histórica positiva do desenvolvimento da relação entre o homem e a natureza, assim como entre os homens, àquela que decifra sua negatividade, como inerência histórica.

Nesse momento, o atributo do homem, o trabalho, se colocaria, ao mesmo tempo, como realização do ser humano e como perda de sua humanidade, como negação do homem. Na Geografia, esse conhecimento se generaliza em meados do século XX, absorvendo a crítica da economia política, na qual ele se baseia; para muitos, numa versão marxista estrutural.

O processo de desumanização do homem, como imanente à formação econômico-social capitalista, passa a incluir o elemento de negação no projeto científico da Geografia. Como no caso de outras ciências, vai exigir uma abertura das teorias e métodos científicos a uma teoria social crítica. O final da década de 1960 foi bastante significativo na superação da separação entre ciência e prática política.

A inflexão, portanto, estaria na metamorfose da positividade em negatividade e a partir daí a experiência dialética vai se incorporando aos métodos em Geografia.

O processo de conhecimento geográfico é, também, um movimento cada vez mais teóricoabstrato de conhecimento, como próprio da Geografia, no sentido da incorporação das mediações abstratas como explicativas; assim como, de explicitação de seus fundamentos sociais. Mas apresenta um desnível em relação à via enunciada acima. A lógica espacial mais abstrata, com vínculos com as ciências físicas e matemáticas, chega à Geografia ainda carregada pela perspectiva positiva do processo de crescimento econômico.

Do ponto de vista lógico-abstrato, a passagem mais complexa é a da metamorfose da lógica espacial em dialética espacial. Mesmo um marxismo na Geografia conviveu com uma lógica espacial formal. A influência, nesse momento, era a do marxismo estruturalista. Apesar das resistências, admite-se, entre os pensadores da Geografia, a influência de Henri LEFEBVRE nessa ruptura, majoritariamente, envolvendo geógrafos americanos. ${ }^{63}$

\footnotetext{
${ }^{63}$ Entre eles: GOTTDIENER, Mark; SMITH, Neil; SOJA, Edward; e HARVEY, David. No Brasil, identifica-se, entre outros autores: ANDRADE, Margarida Maria; CARLOS, Ana Fani Alessandri; DAMIANI, Amélia Luisa; LENCIONI, Sandra; SEABRA, Odette Carvalho de Lima ... e as gerações posteriores, envolvidas e renovando o mesmo trajeto.
} 
A Geografia como totalidade, a partir do final do século XIX, tem como parâmetro a superfície terrestre ${ }^{64}$; e o recorte ou a repartição define uma Geografia Regional potencial, expressão no pensamento do que existe concretamente, sem praticamente mediação - a região aparecendo como auto-evidente, nos inícios da constituição da disciplina geográfica, sintetizando aspectos físicos e humanos existentes -. Num momento posterior, na primeira metade do século XX, a aproximação com o objeto de estudo vai se tornando mais abstrata define-se como seleção de aspectos físicos e humanos, sob a ótica do pesquisado -, à base da influência de HETTNER e HARTSHORNE e os neokantianos. ${ }^{65}$

A lógica do espaço avança nos estudos geográficos, já nos inícios da segunda metade do século $\mathrm{XX}$; ela não se baseia somente em recortes, inclui inúmeros fluxos interpostos e sobrepostos e um movimento de polarização e centralização, como formas de irradiação, a partir dos quais se disseminam processos constituídos nos polos e centros. Aperfeiçoa-se o estudo das hierarquias espaciais. A compreensão abstrata e lógica se torna absoluta e, sob a influência neopositivista ${ }^{66}$, constituem-se modelos como simulacros e, para os que o fazem, eis a verdade e o potencial do espaço, por seu intermédio. Nesse momento, a relação entre o conhecimento geográfico e a tecnocracia se aprofunda. O momento posterior é o da introdução do marxismo e da fenomenologia e a complexificação das lógicas implicadas, em direção à dialética do espaço.

Uma dialética do espaço inclui a dialética do tempo e a potência reprodutora da lógica formal, tornada lógica social ou sócio-lógica. Extraordinária concepção contida na obra de Henri LEFEBVRE, pois dá à lógica formal o estatuto de força real, que permite compreender parte substantiva do que é o processo de reprodução social, incluindo francamente um pensamento sobre o espaço. ${ }^{67} \mathrm{O}$ aprofundamento da lógica dialética, incorporando o espaço, interna e ativamente, permite ampliar o estudo crítico da sociedade contemporânea; nos termos de René LOURAU, leva à crítica do princípio da equivalência

\footnotetext{
64 "O espaço é uma certa extensão de terra com seus acidentes geográficos, um fragmento da película superficial da crosta terrestre onde se misturam os círculos de atividade do indivíduo, das coletividades, do Estado." Esta extensão de terra inclui os subsolos e sua riqueza, as extensões marítimas e o espaço aéreo. Espaços asperamente disputados, contendo parcelas difíceis de definir como próprias à apropriação individual; quer de pessoas ou Estados. Esta extensão é historicamente constituída, sofre as transformações próprias do desenvolvimento técnico, que viabiliza seus usos. (SORRE, Max. Les fondements de la géographie humaine, 1948, p. 101-104)

${ }^{65} \mathrm{O}$ movimento do pensamento geográfico, sistematizado desta forma, recebe o convite de percurso a partir do livro Região e Geografia (LENCIONI, Sandra, 1999).

${ }^{66}$ Um marco desta Geografia - alimentada por ditas revoluções quantitativa e teórica - é a obra de SCHAEFER (originalmente economista, que se reuniu com geógrafos nos Estados Unidos e cujo primeiro texto data de 1953) e, a partir dele, a busca da formulação de leis, que governariam a distribuição espacial; mais do que aos fenômenos, a atenção se dirige aos padrões espaciais. (JOHNSTON, R.J..Geografia e geógrafos, 1986, p.74-75; ver, também, LENCIONI, Sandra, Região e Geografia, 1999).

${ }^{67}$ Cinco indicações indispensáveis de Henri LEFEBVRE, a este propósito: A la lumière du Matérialisme Dialectique - 1. Logique formelle, logique dialectique, 1947 (em português: Lógica formal, lógica dialética, 1975); La vie quotidienne dans le monde moderne, 1968; Au-delà du structuralisme, 1971; La production de l'espace, 2000 (1. a ed. 1974); e De l'État - 4. Les Contradictions de l'État, 1978; entre outras.
} 
ampliado: com "a institucionalização das forças sociais dentro de formas que as negam". ${ }^{68}$ Aqui se chega ao movimento entre a forma e o conteúdo, que servirá de via metodológica profícua:

"[...] uma multiplicidade de lógicas parciais, talvez uma infinidade, tenta se estabelecer; elas querem ocupar os lugares vazios, jogar sobre o abismo uma ponte imóvel, preencher o centro e o ocupar. Há a lógica da ação e da decisão (praxeologia, teoria dos jogos e das estratégias), a lógica do espaço e da coisa em geral, a lógica da troca e da mercadoria, a lógica da equivalência e do contrato, a lógica da recorrência, da escritura, da metalinguagem, a lógica do Estado e do direito, a lógica da moral, etc. Cada lógica (parcial) estabelece uma forma, a explora com rigor, dela extrai necessidades e constrangimentos, extrapola e reduz sem vergonha. Cada lógica, manipulada por um vigoroso e rigoroso pensamento estratégico, se quer absoluta e total [...] Nenhuma lógica, nem a ideo-lógica mais que a sócio-lógica, consegue afastar o negativo, operar a redução satisfatória, eliminar o irredutível (o resíduo)."

Cabe o reconhecimento de que a categoria espaço, enquanto produção do espaço, ilumina esse período dos tempos modernos, crivado de crises: econômica, política ...; ensaiando abrigar a todas, sintetizadas como crise social. A lógica da equivalência, da homogeneização, da metamorfose do material em formal, se generaliza, preenchendo espaços e tempos, impedindo o próprio movimento da alienação do tempo: "a forma de existência imediatamente dada do presente como transição para a sua auto-superação no processo histórico." ${ }^{70} \mathrm{O}$ processo de reconhecimento do sujeito como tal é também um processo de diferenciação em relação ao objeto. A objetivação, como momento da subjetivação, é um processo de alienação necessária. "O tempo é a alienação necessária, como mostrava Hegel, o meio em que o sujeito se realiza se perdendo, torna-se outro para se tornar a verdade de si mesmo." ${ }^{71}$ A forma mercantil interfere qualitativamente nas formas de objetividade, no conjunto dos fenômenos subjetivos e objetivos.

“[...] O tempo perde, assim, o seu caráter qualitativo, mutável e fluido: ele se fixa num continuum delimitado com precisão, quantitativamente mensurável, pleno de 'coisas' quantitativamente mensuráveis (os 'trabalhos realizados' pelo trabalhador, reificados, mecanicamente objetivados, minuciosamente separados do conjunto da personalidade humana); tornase um espaço." 72

O processo de reificação vai incluindo toda a vida social e essa paralisia de tempo em espaço recebe, para Henri LEFEBVRE, do Estado uma força extraordinária: o curvar-se do

\footnotetext{
${ }^{68}$ LOURAU, René. El Estado y el inconsciente - Ensayo de sociología política, 1980.

${ }^{69}$ LEFEBVRE, Henri. Au-delà du structuralisme, 1971, p. 9.

${ }^{70}$ LUKÁCS, Georg. História e Consciência de Classe - estudos sobre a dialética marxista, 2003, p. 44 (citando Hegel).

${ }^{71}$ DEBORD, Guy. La société du spectacle, 1992, p. 158.

${ }^{72}$ LUKÁCS, Georg. História e Consciência de Classe - estudos sobre a dialética marxista, 2003, p. 205 (citando MARX).
} 
social no político ${ }^{73}$; ou melhor, no estatista, no sentido do desdobramento de formas de institucionalização, da generalização do princípio de equivalência a todas as formas sociais incluindo, portanto, a questão do Estado e da instituição. ${ }^{74}$

\begin{abstract}
"O Estado moderno se destaca de uma história porque ele a contém e dela resulta. Ao mesmo tempo, ele se destaca da mundialidade em formação e isto por muitos motivos; mundializado ele mesmo, ele continua com o mercado mundial, com as firmas mundiais, com a constituição do espaço mundial. Quem diz 'mundialidade' diz espacialidade e não temporalidade. 0 tempo domina o espaço no curso da história, depois, o espaço predomina sobre o tempo. Espacialidade, temporalidade, historicidade, mundialidade, estes conceitos globais, esclarecedores, são pouco 'operacionais', como dizem os pragmáticos e os tecnocratas, e pouco 'pontuais'.

Período cheio de surpresas. O termo emprestado à filosofia, a 'problemática', parece frágil para designar o conjunto de crises, de fatalidades, incertezas, que emergem ou se escondem na sombra no curso dessa transição. Os 'problemas' se entrecruzam, agravam-se, desvendam-se ou se mascaram uns nos outros [...] Quem diz 'aporia' diz questão cujos próprios termos permanecem mal formulados, incertos." ${ }^{\prime 75}$
\end{abstract}

Nesse contexto, apesar de inúmeras falências, do político, do econômico, ainda prevalece a força do discurso que aparece como eficaz, que problematiza menos e mesmo assim se apresenta competente. E competente é aquele que não envereda pelas tramas das contradições, pois considerá-las parece ineficaz e incoerente, um discurso envelhecido, a direção de uma transformação impossível (ilusória). Num determinado sentido, trata-se da ideologia da comunicação: objetivando superar bloqueios de comunicação e não identificar contradições ou conflitos ${ }^{76}$. A considerar, também, a renovação das concepções apocalípticas; e estas atingem, especialmente, à população sem projeto político no horizonte.

Então, estamos estabelecidos no mundial, no espacial.

A reprodução da sociedade contemporânea, lida apressadamente, pode aparecer como fruto da inércia, não exigindo projetos ou estratégias, não exigindo, assim, problematização. Há mais de meio século, que a história parece peso morto ou se disfarça em folclore solvável através do turismo, ou ainda revigora a economia urbana financeirizada, nas "revitalizações" dos centros "históricos" urbanos. É quando a historicidade perde importância, prevalecendo uma instalação no existente, apesar de desconfortável para muitos e dilacerante para amplas camadas sociais, sem perspectivas claras ou projetos sociais de mudanças ou

\footnotetext{
${ }^{73}$ LOURAU, René. El Estado y el inconsciente - Ensayo de sociología política, 1980, p. 45.

${ }^{74}$ Op. cit., p. 92-93.

${ }^{75}$ LEFEBVRE, Henri. De l'État - 4. Les Contradictions de l'État, 1978, p. 326-327.

${ }^{76}$ LOURAU, René. El Estado y el inconsciente - Ensayo de sociología política, 1980, p. 107 (citando LEFEBVRE).
} 
movimentos radicais. Estes prevalecem ao nível do residual. Nesse momento, exatamente, exige-se a acuidade no tratamento das transformações, das transições, do movimento do real, das contradições, que parecem assim residuais - vividas de modo ambíguo, atenuadas pela alienação cotidiana, mesmo para aqueles que perdem toda estabilidade nas contingências da vida -, e, ao invés de crises cruciais, geram tédio, mal estar, insatisfação, apatia ou, inversamente, violência; em síntese, quando se produzem os espectadores. Semelhante "estado de espírito" envolve a revitalização das leituras existencialistas ou até existenciais; mas o que se busca, como plano necessário, ainda a discernir, é o da relação entre a consciência privada e a consciência social. Expondo a importância das contradições internas nos aproximamos, com instrumentos mais adequados, do imenso universo da mercadoria no qual estamos afundados e confundidos; submetidos, extensa e intensivamente. ${ }^{77}$

\section{O espacial é a imersão do homem, como sociedade e indivíduo, no mundo da} mercadoria.

Parece um momento adequado mais à informação do que à necessidade de desvendamento. A falência das explicações teóricas e o avanço de um certo empirismo coincidem com o predomínio do mundial sobre o histórico. Do espacial sobre o temporal. Do que tem expressão espacial no mundial, do que parece assemelhado à estabilidade e não ao movimento e ao processo. Um pensamento que pensa a formação, a transição, parece inadequado, exatamente quando se ratifica sua potência desvendadora, porque ele, especialmente, é o pensamento que problematiza, desconfia da estabilidade aparente, da mobilidade quase ínfima. Põe a nu, como estratégia, o que se tem como dado e fato. Desconfia do fim da história, que a mundialidade parece indicar. Mundialidade que, num momento anterior, o da sua constituição, envolveu a força da nação, a aceitação pela classe trabalhadora de uma realidade nacional, ou até regional, que esfumou sua condição social e a luta que implicava. Envolto em guerras, crises, tratados, colonizações, mal elucidados, houve a ascensão do Estado e da nação, no lugar da classe, da universalidade racional e do internacionalismo. ${ }^{78}$

\footnotetext{
${ }^{77}$ DEBORD, Guy. La société du spectacle, 1992.

${ }^{78}$ Verificar, entre outros trabalhos de Henri LEFEBVRE, a abertura do livro: Du Contrat de Citoyenneté (GROUPE DE NAVARRENX, 1990).
} 
Estabelecemos, agora, uma hipótese, a de que a mundialidade, a do mundo da mercadoria, repõe essa universalidade, aquela dos movimentos sociais globais que a negam.

Então, em seguida, é preciso considerar que esse mergulho, que iniciamos, abstrato, teórico, de aparência vazio, e até neutro, o 'puro' conhecimento, traduz-se na tentativa de encontrar uma via do sentido real da espacialidade. Esta discussão abstrata é o caminho para encontrar a singularidade da realidade social, instalada no mundial e no espacial.

Para desvendar o mundial, o espacial, que caracteriza o fim do século XX, e se estende e se amplia no início do século XXI, faz-se necessário desvendá-lo como lógico, uma sócio-lógica, a lógica traduzida em estratégia real, se realizando no terreno.

A essência abstrata do espacial é a lógica, mais ainda, a lógica formal. Ela alimenta o planejamento, a informação, a produção do espaço, a deterioração da dialética do tempo. $\mathrm{E}$ somente um pensamento, que localize essa lógica e a transcenda, revela a dialética do espaço. Então, haveria um movimento a enfrentar: a passagem da dialética do tempo para aquela do espaço, cuja mediação envolve o reconhecimento de uma lógica tornada sóciológica, isto é, a lógica que saiu do plano teórico e se tornou prática; num segundo momento, trata-se de reconhecer que ela não se afirma de forma absoluta, renovando-se as contradições internas. Há o que resiste, como possível-impossível. ${ }^{79}$

Sobre a contribuição de Henri LEFEBVRE, diz Edward SOJA em Geografias Pós-Modernas. ${ }^{80}$ :

"Sugiro que este personagem - Henri Lefebvre -, talvez o menos conhecido e mais mal interpretado dentre as grandes figuras do marxismo do século $\mathrm{XX}$, foi, acima de tudo e de todos, a origem da geografia humana crítica pósmoderna, a fonte primordial do ataque ao historicismo e da afirmação do espaço na teoria social crítica." ${ }^{81}$

"[...] Lefebvre define uma ampla problemática espacial do capitalismo e a eleva a uma posição central dentro da luta de classes, inserindo as relações de classe nas contradições configuradoras do espaço socialmente organizado. Ele não afirma que a problemática espacial sempre tenha tido essa centralidade. Tampouco apresenta a luta pelo espaço como um substituto ou uma alternativa à luta de classes. Em vez disso, afirma que nenhuma revolução social pode ter êxito sem ser, ao mesmo tempo, uma revolução conscientemente espacial [...] A desmistificação da espacialidade revelará as potencialidades de uma consciência espacial revolucionária, os fundamentos materiais e teóricos de uma práxis espacial radical.." ${ }^{12}$

\footnotetext{
${ }^{79}$ LEFEBVRE, Henri. Au-delà du structuralisme, 1971.

${ }^{80}$ SOJA, Edward. Geografias Pós-Modernas, 1993.

${ }^{81}$ Op. cit., p. 54.

${ }^{82}$ Op. cit., p. 116.
} 
Como via da historicidade - negativamente posta -, substituída pela mundialidade - como instalação no espacial - podemos refletir o espacial, resolvido em anéis em espiral de incorporação de lógicas sociais ${ }^{83}$, das mais abstratas às mais concretas: lógica formal (a da identidade formal, anulação da diferença e da contradição); lógica da equivalência (a da mercadoria; a igualização violenta do desigual) ${ }^{84}$; lógica da equivalência ampliada (a força das instituições, das representações, da hierarquização) ${ }^{85}$; lógica da separação (a potência prática da sociedade, perdida e inconsciente para ela, realizando a unificação na separação como espetáculo) ${ }^{86}$. São formas de manutenção no existente; de negação do tempo histórico total, de reprodução social.

Cada uma dessas sócio-lógicas contém às outras. Há dois movimentos incluídos: da mais abstrata à mais concreta, esclarecendo-se os fundamentos recíprocos. Da mais concreta à mais abstrata, pondo-se o modo de existência ou de concretização dessas lógicas. Importa utilizar essa classificação no sentido de esclarecer o espacial como redução da experiência do tempo e o emprego do tempo como apropriação do espaço, expressando "o que a sociedade pode fazer, mas nessa expressão o permitido se opõe absolutamente ao possível." ${ }^{87}$

Os conteúdos dessa discussão passam pelo par produção do espaço e apropriação do espaço, enquanto contraditório. Busca-se um pensamento incomodado com a redução e os constrangimentos à apropriação do espaço, fundamentos da reprodução social crítica contemporânea.

A relação, no seu limite mais abstrato, entre a lógica formal e o espaço visa esclarecer uma prática espacial dos nossos tempos, bem como introduzir um componente metodológico considerado potente para decifrar os fundamentos da relação entre espaço e reprodução social.

Milton SANTOS chega, através da concepção de meio técnico científico informacional, aos espaços de racionalidade, como "'desencantamento do espaço geográfico', hoje tendente a ser completamente racionalizado, sujeito a regras preestabelecidas que incluem sua própria substância": "o espaço geográfico, transformado em território da racionalidade", "um

\footnotetext{
${ }^{83}$ Grade composta, com certo desvio, a partir de LEFEBVRE, Henri. La vie quotidienne dans le monde moderne, 1968.

84 "A violência como inerente ao econômico, da mesma forma que a política." (LEFEBVRE, Henri. De I' Etat - 3. Le mode de production étatique, 1977, p.24.)

${ }^{85}$ LOURAU, René. El Estado y el inconsciente - Ensayo de sociología política, 1980

86 "[...] Seguindo o progresso da acumulação dos produtos separados e da concentração do processo produtivo, a unidade e a comunicação se tornam o atributo exclusivo da direção do sistema. O triunfo do sistema econômico da separação é a proletarização do mundo." (DEBORD, Guy. La société du spectacle, 1992, p.28)

${ }^{87}$ Op. cit., p. 27. Neste momento, DEBORD tratava da sociedade do espetáculo e da separação como o alfa e o ômega do espetáculo.
} 
espaço que pode ser manipulado como uma coisa", definindo "o esquema de nossa ação possível." E "a partir dessa racionalidade hegemônica, instalam-se paralelamente contraracionalidades"; "na verdade, e substancialmente, outras formas de racionalidade". ${ }^{88}$ Embora considerando a impossibilidade da racionalidade absoluta se realizar como tal, o que se realiza não é estritamente particular, mas equivale através do espaço, inclusive materialmente, a um processo de totalização, "o movimento conjunto do todo e das partes", o modo de se concretizar a totalidade potencial. Econômica, política e socialmente o espaço vai regendo esse modo de operar a totalidade concreta. "O movimento da totalidade para existir objetivamente é um movimento dirigido à sua espacialização, que é também particularização." ${ }^{89}$

Se a lógica adere ao espaço, é porque ela move formas de existência social e individual.

"A história que ameaça este mundo crepuscular é também a força que pode submeter o espaço ao tempo vivido. A revolução proletária é esta crítica da geografia humana através da qual os indivíduos e as comunidades devem construir os sítios e os acontecimentos correspondentes à apropriação, não mais somente de seu trabalho, mas de sua história total." ${ }^{90}$

Uma Geografia contemporânea, que atualiza uma Geografia crítica - de presença autogestionária e subversiva, portanto, não estatista - questiona a economia e o Estado. Esta é a grande aquisição desses novos tempos: generalizar a crítica do processo de desumanização, inerente às ações econômicas e estatistas. Portanto, a relação com a prática já não é, necessariamente, sob a mediação do Estado.

Cedo, a Geografia reconheceu o plano das estratégias. Ele era combinado com o tratamento do objeto no interior de uma lógica formal. O que é próprio desta lógica e difícil de romper é a separação entre os elementos de uma relação e o estabelecimento da exterioridade recíproca desses elementos, no seu desenvolvimento. É possível reconhecer certas relações de causalidade, mas não a relação constitutiva interna dos elementos entre si, nos termos da compreensão da dupla e interna determinação entre eles e de um processo negativo implicado. E, por isso, se torna mais complicado encontrar um tratamento do objeto em movimento, uma noção de processo. Pode ser elucidativo verificar, por exemplo, o tratamento dos elementos constitutivos da mercadoria - valor de uso e valor de troca -, como um conceito básico e presente numa geografia mais crítica; entretanto, é comum

\footnotetext{
${ }^{88}$ SANTOS, Milton. A Natureza do Espaço, 1996, capítulo 13. Os espaços da racionalidade, p. 230-247.

${ }^{89}$ Op. cit., capítulo 4, O espaço e a noção de totalidade, p. 91-103.

${ }^{90}$ DEBORD, Guy. La société du spectacle, 1992, p. 172.
} 
manter esses elementos autônomos, como se fosse possível falar de um ou de outro separadamente. Tal coisa tem valor de uso; tal outra, valor de troca... A relação interna e negativa entre esses elementos, na definição da mercadoria, ainda é de difícil discernimento.

Uma Geografia que inclua a dialética e, ainda, a relação entre estratégia e dialética pode nos ajudar a compreender os termos da modernização do mundo. É necessário examinar o processo de modernização extensiva e intensivamente. $E$, neste duplo, os termos da deterioração da vida social e humana e da própria economia.

Resta introduzir que, sobre esse substrato total e homogêneo do espaço abstrato ${ }^{91}$, há diferenciações geográficas: “o desenvolvimento desigual é a marca registrada da Geografia do Capitalismo." ${ }^{92}$ Sendo que ao capital interessa a produção de diferenciações, que definem a apropriação diferencial de mais-valia extraordinária, bem como o processo do capital tende à igualização das condições de produção social, segundo médias sociais, que os mecanismos de mercado vão potencialmente determinando. As desigualdades materiais do processo econômico-social têm lugar importante na análise das sociedades modernas.

Podemos incluir aqui a ideia de subsunção formal ao capital, isto é, o capitalismo não se resolve no modo de produção especificamente capitalista, mas é uma complexa formação econômico-social. ${ }^{93}$

A materialidade dos processos sociais sempre teve acento nos estudos geográficos. Dizia-se, inclusive, que os geógrafos tinham um gosto pelo valor de uso. A ciência do espaço é uma ciência do uso, assevera Henri LEFEBVRE. E, neste momento, o uso esclarece o existente e contradiz a abstração do valor de troca. ${ }^{94}$ Uma Geografia crítica, a partir de MARX, que

\footnotetext{
${ }^{91} \mathrm{O}$ espaço abstrato é o espaço produzido pelo capitalismo. "O espaço abstrato funciona 'objetalmente' como conjunto de coisas-signos, com suas relações formais [...] Este espaço formal e quantificado nega as diferenças [...]" (LEFEBVRE, Henri. La production de l'espace, 2000, p. 60-61).

"Sobre o espaço abstrato já se sabe muitas coisas. Produto da violência e da guerra, ele é político, e instituído por um Estado, portanto, institucional. À primeira vista, ele parece homogêneo; efetivamente, ele serve de instrumento às potências que fazem tábua rasa do que resiste e do que ameaça, - em resumo, as diferenças." (Op. cit., p. 328)

A concepção de espaço abstrato atravessa todo o livro La production de l'espace. Na análise do processo social, trata-se de examinar a forma triádica de realização do valor, incluindo a extensão e intensificação do processo abstrato de realização da mercadoria e do valor, através da mobilização da propriedade da terra e da produção do espaço, enquanto espaço abstrato. (ver, também, LEFEBVRE, Henri. Une pensée devenue monde, 1980, O binário e o triádico, p. 179-213)

${ }_{92}$ SMITH, Neil. Desenvolvimento Desigual - natureza, capital e a produção de espaço, 1988, p. 16.

93 “[...] faz parte da natureza da questão o fato de que a subsunção do processo de trabalho ao capital se opere à base de um processo de trabalho preexistente, anterior a essa subsunção do capital, e que se configurou à base de diferentes processos de produção anteriores e de outras condições de produção; o capital se submete a determinado processo de trabalho existente [...] Se nesses processos de trabalho tradicionais, que ficaram sob a direção do capital, se operam modificações, estas só podem ser consequências paulatinas da subsunção de determinados processos de trabalho tradicionais ao capital [...] chamamos a subsunção até aqui considerada do processo de trabalho [...] ao capital, de subsunção formal do trabalho ao capital. " (MARX, Karl. O capital - Livro I, Capítulo VI (Inédito), 1978, p. 52-53.

94 "A ciência do espaço seria então ciência do uso, enquanto que as ciências especializadas, ditas ciências sociais, fazem parte da troca e se querem ciências da troca (da comunicação e do comunicável: economia política, sociologia, semiologia, informática, etc.). Sob esta ótica, a ciência do espaço se aproxima da materialidade, da qualidade sensível, da naturalidade mas colocando o acento na segunda natureza: a cidade, o urbano, a energética social [...] a apropriação recebe um privilégio teórico e prático. Como uso, contra a troca e a dominação. " (LEFEBVRE, Henri. La production de l'espace, 2000, p. 425)
} 
amplia a discussão das abstrações concretas, no corpo dos estudos geográficos, acaba por envolver o momento material dos processos sociais, como insurgente, constituindo formas de resistência.

O espectro das análises em Geografia vai da relação imediata e cotidiana com os objetos, através dos quais se materializam as relações do homem com o ambiente, e que servem como testemunhos de práticas, que podem não existir mais, constituindo um elemento da singularidade dos lugares à observação de fluxos materiais, que explicam as trocas e relações internacionais - de mercadorias, de população -; portanto, definindo uma visão de conjunto, uma Geografia geral. A ideia da Geografia como descrição da superfície terrestre já inclui, expressamente, o olhar sobre o acervo material instalado no terreno. Evidentemente, envolve a complexidade do estudo das técnicas e instrumentos como momento necessário do desvendamento das relações sociais ${ }^{95}$ - a fluidez do movimento sobre o espaço, dependendo das infraestruturas materiais no espaço ${ }^{96}$-; incluindo a introdução de técnicas e inovações em oposição aos anteriores modos de vida. ${ }^{97} \mathrm{~A}$ atualização da geografia, definida como clássica, e que aqui nos serve de argumento, não negou de forma absoluta o papel das coisas sensíveis nas práticas sócio-espaciais, mas como ponto de ruptura nega-as como exterioridade pura e simples ou modo de identificação absoluto, pois senão estaríamos no limite da coisificação.

A noção de diferenciação espacial permite conceber que os espaços - campos de práticas e sociedades - são atingidos de modo desigual por um mesmo processo, que, portanto, este se realiza de modo desigual.

Yves LACOSTE chega à ideia de espaços de conceptualização para discernir diferentes níveis de análise, compatíveis com a natureza dos problemas a decifrar - econômicos; políticos e sociais -, evitando o a priori de um tipo de espaço. Fazia, assim, a crítica às monografias regionais.

\footnotetext{
“No plano do conhecimento, não existe um nível de análise privilegiado; nenhum deles é suficiente, pois o fato de tomar em consideração tal espaço como campo de observação vai permitir apreender determinados fenômenos e certas estruturas, mas conduz à deformação ou à ocultação de outros fenômenos e de outras estruturas cujo papel se não pode menosprezar a priori e que não se podem negligenciar. É portanto indispensável colocarmo-nos a outros níveis de análise, tomando em
}

\footnotetext{
95 "[...] cada lugar é uma combinação de técnicas qualitativamente diferentes, individualmente dotadas de um tempo específico - daí as diferenças entre lugares. Por isso mesmo, a Geografia pode ser considerada como uma verdadeira filosofia das técnicas." (SANTOS, Milton. Espaço e método, 1985, p. 12-13)

${ }^{96}$ HARVEY, David. El nuevo imperialismo, 2004, p. 87.

${ }^{97}$ SORRE, Max. Les fondements de la géographie humaine, 1948.
} 
consideração outros aspectos. Em seguida, é necessário fazer a articulação de todas essas diferentes observações pois que são função daquilo a que poderíamos chamar espaços de conceptualização diferentes." ${ }^{\prime 98}$

O caminho da Geografia foi o de dialetizar essas escalas espaciais apropriadas à interpretação de subconjuntos de fenômenos. Neil Smith ${ }^{99}$, de modo feliz, concebe como produção de escalas geográficas, acompanhando de modo mais refinado o processo de formação e as estruturas de reprodução in ato. É menos articulação de estruturas fixas, mais processo de produção e estruturação sociais.

As diferenciações geográficas elucidam a complexidade da sociedade que se resolve em tendências de desenvolvimento, "numa transformação qualitativa ininterrupta da estrutura da sociedade", e não no puramente capitalista.

"A impossibilidade econômica da acumulação numa sociedade puramente capitalista não se expressa, portanto, com o 'término' do capitalismo, tão logo o último produtor não capitalista seja expropriado, mas com as ações que a aproximação (empiricamente ainda bastante distante) dessa situação impõe à classe dos capitalistas: na colonização febril, na disputa pelos mercados e pelas matérias-primas, no imperialismo e na guerra mundial etc." 100

Importante também destacar que certas formas derivadas do capital - o capital comercial, monetário ou não -, exerceram uma função negativa de dissolução das formas originárias da produção. Assim, o argumento é o da superação do fato da mera empiria em direção a uma realidade superior, que é a das tendências ${ }^{101}$; e as diferenças geográficas não se resolvem na articulação de espaços desiguais - expressando diferentes modos de produção, por exemplo, ao gosto estruturalista -, mas num processo complexo que inclui essas diferenciações e desigualdades, como momentos da formação econômico-social capitalista se realizando. Ainda sobre a dissolução de formas originárias da produção, na atualidade, é preciso considerar, em certos casos, paradoxalmente, o papel da política de proteção ambiental e o do turismo na constituição de novos territórios de valorização/capitalização econômica, em detrimento das práticas sociais anteriores. Poderíamos definir esse processo de despossessão como uma acumulação primitiva do espaço, ainda em curso. ${ }^{102} \mathrm{Em}$ países

\footnotetext{
${ }^{98}$ LACOSTE, Yves. A Geografia serve antes de mais nada para fazer a guerra. 1979, p. 47-48

${ }^{99}$ SMITH, Neil. Contornos de uma política espacializada: veículos dos sem-teto e produção de escala geográfica, 2000.

${ }^{100}$ LUKÁCS, Georg. História e Consciência de Classe - estudos sobre a dialética marxista, 2003, p. 365.

${ }^{101}$ Op. cit., p. 364 e 366.

102 [O capitalismo] não somente integrou o espaço preexistente, inserindo-o em sua extensão; ele instituiu setores novos, inserindo-os na sua expansão. Os lazeres se tornaram na Europa e nos grandes países industrializados avançados uma indústria de primeira importância. Conquistaram-se para os lazeres: o mar, as montanhas e até os desertos. A indústria dos lazeres se conjuga com aquela da construção [...]” (LEFEBVRE, Henri. Le droit à la ville suivi de Espace et politique. 1974, p. 264-265)
} 
como o nosso, trata-se de uma face da extensão e intensificação do capitalismo a ser cuidadosamente examinada. O tratamento imbecilizado e imbecilizador das populações tradicionais, muitas de camponeses, em áreas de proteção ambiental e de turismo, indicando, entre as estratégias, a educação ambiental, no primeiro caso, e, no segundo, decifrando a capacidade de carga desses espaços (de absorção de turistas), chega às raias do bizarro. Bizarro com teias institucionais em todas as escalas espaciais, inclusive, a mundial; que, aliás, serve de parâmetro. ${ }^{103}$

Ao esclarecer a noção de formação econômico-social em MARX E LENIN, a partir da obra de Henri LEFEBVRE, José de Souza MARTINS a conceitua englobando a de desenvolvimento desigual e a de sobrevivências na estrutura capitalista de formações e estruturas anteriores: "as forças produtivas, as relações sociais e as superestruturas (políticas, culturais) não avançam igualmente, simultaneamente, no mesmo ritmo histórico." ${ }^{104}$ O sentido é o da coexistência dos tempos históricos, incluindo, além do passado e do presente, o futuro, o possível; recuperando temporalidades desencontradas e coexistentes: "o atraso do real em relação ao possível, o social em relação ao econômico [...] concepções da vida e da História apoiadas em extensões de tempo que não seriam identificadas a partir de procedimentos decorrentes da ideia de etapas e sucessões de etapas históricas." ${ }^{105}$

SMITH anuncia uma passagem, valendo-se de LENIN e MARX, da integração espacial formal para uma real integração espacial: "da expansão geográfica absoluta do capital para a produção do espaço através da diferenciação espacial interna". ${ }^{106}$ Ainda a considerar um movimento desigual entre o político e o econômico: os territórios nacionais apresentam um ritmo de transformação aquém da voracidade do processo econômico, quase apresentando a "fossilização das fronteiras das nações-Estados como um meio de controle político" e

Sobre o inacabamento da teoria da acumulação primitiva ver: LEFEBVRE, Henri. La production de I'espace, 2000, p. 303-309. Quando o autor responde à questão, como a acumulação primitiva foi possível, através da análise do espaço emergido no século XII, espaço laicizado, integrando a lógica e reconstituindo o direito. Também, sobre a necessidade de revisão dos estudos da experiência da acumulação primitiva, ver LEFEBVRE, Henri. Une pensée devenue monde, 1980, p. 188-189.

${ }^{103}$ Deve-se mencionar a leitura impar de José de Souza MARTINS sobre a concomitância da expropriação e da exploração. "Em nosso país, nos dias de hoje, o capitalismo articula num só tempo, ainda que em espaços distintos, a expropriação e a exploração, processos que, a rigor, se deram separadamente na história clássica do capital." (Expropriação e violência, 1980, p. 16).

${ }^{104}$ MARTINS, José de Souza. As temporalidades da história na dialética de Lefebvre. IN: MARTINS, José de Souza (ORG.). Henri Lefebvre e o retorno à dialética, 1996, p. 17 (citando Lefebvre)

105 Op. cit., p. 20-21. MARTINS identifica em LEFEBVRE o reconhecimento de uma dupla complexidade da realidade social: horizontal e vertical. Com o olhar teoricamente informado, o pesquisador deve reconstituir a diversidade das relações sociais, a complexidade horizontal da vida social, ao nível da descrição. O segundo momento seria analítico-regressivo; ele contém um esforço vertical e analítico de datação precisa das relações sociais. No tempo vivido, há combinação prática de coisas, relações e concepções não contemporâneas. 0 terceiro momento, histórico-genético, de reencontro do presente, elucidando nele as possibilidades do vivido. Assim, sinteticamente, define-se o método regressivo-progressivo, legado de MARX, recuperado criativamente por LEFEBVRE. (Op. cit., p. 20-23)

106 “O colonialismo funcionou como um tipo de fixo espacial 'exterior', embora transitório, mas da mesma forma que a integração espacial na escala global se tornava real e não simplesmente formal, o espaço geográfico exterior negava sua exterioridade. Assim como a primeira natureza veio a ser produzida dentro e como parte da segunda natureza, o espaço 'exterior' era internalizado e produzido dentro e como parte da Geografia global do capitalismo." (SMITH, Neil. Desenvolvimento Desigual - natureza, capital e a produção de espaço, 1988, p. 202) 
propondo nesse momento da mundialização o desenvolvimento das regiões supranacionais, como necessidade econômica. De fato, a economia do capital é uma economia relativa. Contudo, os Estados-nacionais, como entidades territoriais, historicamente constituídas, reproduzem mecanismos ainda funcionais e eficientes politicamente, apesar das formas estatistas internacionalizadas: FMI e Banco Mundial ... É o que HARVEY define por lógica territorial de poder, como marco territorial aonde os processos moleculares de acumulação de capital operam, desde os Estados nacionais até as instituições infra e supra estatistas. (Quanto ao império norte-americano, ele fala em complexo Wall Street - Departamento do Tesouro estadunidense - FMI, beneficiando o capital financeiro). ${ }^{107}$

"O capital produz escalas espaciais distintas (espaços absolutos) dentro dos quais o impulso para igualização está concentrado. Mas só pode ser realizado por aguda diferenciação e por continua re-diferenciação do espaço relativo, tanto entre as escalas quanto dentro delas. As escalas por si mesmas não são fixas [...]"108

A teoria do desenvolvimento desigual consubstancia o conhecimento das diferenciações geográficas em todos os níveis e, especialmente, é a experiência conscientizada das relações entre as diferenças sensíveis e sua metamorfose em determinações formais dos processos econômicos e políticos. ${ }^{109}$

Inversamente, a produção de contra-poderes, de contra-espaços, em que nível se daria? Aquele do particularismo militante ${ }^{110}$ ou da mobilização da multidão ${ }^{111}$ ? Seja qual for a resposta, diante do campo cego das ações revolucionárias, estas incluem acontecimentos explosivos, momentos e situações, completamente espaço-temporais. ${ }^{112}$

\footnotetext{
${ }^{107}$ HARVEY, David. El nuevo imperialismo, 2004. “O Estado é a entidade política, o organismo político, mais capacitado para orquestrar os dispositivos institucionais e manipular as forças moleculares de acumulação de capital afim de preservar a pauta de assimetrias na troca mais proveitosa para os interesses capitalistas dominantes que funcionam em seu marco." (Op. cit. p. 109)

${ }^{108}$ SMITH, Neil. Desenvolvimento Desigual - natureza, capital e a produção de espaço, 1988, p. 211.

109 "As condições geográficas desiguais não surgem simplesmente da distribuição desigual de recursos naturais e vantagens posicionais, mas derivam em grande medida da elevada concentração da riqueza e poder em certos lugares produzida pelas relações assimétricas de troca." (HARVEY, David. El nuevo imperialismo, 2004, p. 42)

110 HARVEY, David. Espaços de Esperança. 2004. Sobre as lutas particulares em lugares e momentos particulares como origem das lutas gerais.

${ }^{111}$ HARDT, Michael e NEGRI, Antonio. Multitud - Guerra y democracia en la era del Império, 2004. A multidão como alternativa ao Império e nas diferenças da multidão, encontrar o comum, como nova comunicação, colaboração e cooperação.

112 Internationale Situationniste, n.o 4, junho de 1960. IN: Internationale Situacionniste, 1997; LEFEBVRE, Henri. Teoria dos Momentos. IN: La Somme et le Reste, 1989 (1959), p. 637-655 e Critique de la Vie Quotidienne II - Fondements d'une sociologie de la quotidienneté, 1980 (1962), 340-357.
} 


\section{BIBLIOGRAFIA BÁSICA}

CARLOS, Ana Fani Alessandri; DAMIANI, Amélia Luisa; e SEABRA, Odette Carvalho de Lima (Orgs.). O espaço no fim de século: a nova raridade. São Paulo: Contexto, 1999.

DAMIANI, Amélia Luisa. Espaço e Geografia: Observações de Método. Elementos da obra de Henri Lefebvre e a Geografia. Ensaio sobre Geografia Urbana a partir da Metrópole de São Paulo. Livre-Docência. FFLCH, DG, USP, 2008.

DEBORD, Guy. La Société du Spectacle. Paris: Gallimard, 1992.

GEORGE, Pierre; GUGLIEMO, Raymond; LACOSTE, Yves e KAYSER, Bernard. A Geografia Ativa. São Paulo: Difusão Européia do Livro/EDUSP, 1966.

HARVEY, DAVID. Justice, Nature and the Geography of Difference. Massachusetts: Blackwell, 1999.

. El Nuevo Imperialismo. Madri: Akal, 2004.

. Espaços de Esperança. São Paulo: Loyola, 2004.

JOHNSTON, R.J.. Geografia e Geógrafos (A Geografia Humana anglo-americana desde 1945). São Paulo: Difel, 1986.

LACOSTE, Yves. A Geografia Serve Antes de Mais para Fazer a Guerra. São Paulo: AGB, 1979.

LEFEBVRE, Henri. Au- delà du structuralisme. Paris: Anthropos, 1971.

. De l'État - 4. Les Contradictions de l'État Moderne. Paris: Union Générale d'Éditons, 1978.

. Une Pensée Devenue Monde - Faut-il abandonner Marx ?. Paris:

Fayard, 1980.

. La Presencia y la Ausencia - Contribución a la teoría de las representaciones. México: Fondo de Cultura Económica, 1983.

. La Production de l'Espace. Paris: Anthropos, 2000, 4. edição. 
. Méthodologie des Sciences (Inédit). Paris: Anthropos, 2002.

LENCIONI, Sandra. Região e Geografia. São Paulo: EDUSP, 1999.

LOURAU, René. El Estado y el inconsciente - Ensayo de sociología política. Barcelona: Kairós, 1980.

LUKÁCS, Georg. História e Consciência de Classe - estudos sobre a dialética marxista. São Paulo: Martins Fontes, 2003.

MARTINS, José de Souza (org.). Henri Lefebvre e o retorno à dialética. São Paulo: Hucitec, 1996.

MARX, Karl. Elementos Fundamentales para la Crítica de la Economia Política (Grundrisse) 1857-1858. México: Siglo Veintiuno, 1977, volumes 1 e 2. . Manuscrits de 1844. Paris: Flammarion, 1996.

SANTOS, Milton. A Natureza do Espaço. Técnica e tempo. Razão e emoção. São Paulo: Hucitec, 1996.

SMITH, Neil. Desenvolvimento Desigual - natureza, capital e a produção de espaço. Rio de Janeiro: Bertrand Brasil, 1988.

SOJA, Edward. Geografias Pós-Modernas - A Reafirmação do Espaço na Teoria Social Crítica. Rio de Janeiro: Jorge Zahar, 1993. 